\title{
IAWS News
}

\section{Robert Evans}

(C) Springer-Verlag Berlin Heidelberg 2015

One of the activities of our academy is the global promotion of wood science through direct interaction with a wide range of scientific institutions, many of which become supporting members. In addition to our Annual Plenary Conferences, the executive committee looks for new opportunities by meeting with scientific and industrial organisations in various countries with whom we can create or strengthen long-term relationships.

This year, the executive committee is planning to hold a meeting in Vietnam in May with organisations including the Vietnam Academy of Forest Science and the Vietnam Timber Association.

Although Vietnam suffered considerable losses of native forest cover in the latter half of the 20th century, great gains have been made in recent decades. Vietnam is in the process of building up its wood processing industries based on its rapidly expanding plantation of wood resources.

My own country, for example, has long contributed scientific expertise funded in part by the Australian Centre for International Agricultural Research. The most common plantations in Vietnam are of Australian eucalypts and acacias, totalling about two million hectares. Much of the pioneering work was done in collaboration with France, China and Sweden. Last year, an IUFRO conference was held in Vietnam on 'Sustaining the Future of Acacia Plantation Forestry'. We look forward to building on these relationships with an emphasis on wood science. 